Yayın Geliş Tarihi: 14.10.2020

Yayına Kabul Tarihi: 11.12 .2020

Online Yayın Tarihi: 31.12.2020

http://dx.doi.org/10.16953/deusosbil.810354
Dokuz Eylül Üniversitesi

Sosyal Bilimler Enstitüsü Dergisi

Cilt: 22, Say1: 4, Y11: 2020, Sayfa: 1501-1520

Araştırma Makalesi

\title{
YAŞAM VE ÖLÜM ARASINDA BİR UĞRAK OLARAK YAŞLILIK ${ }^{1}$
}

Özlem DUVA KAYA*

$\ddot{O} z$

Yaşlanma ve yaşlılık konusu, özellikle modern dönem içerisinde genellikle ölüm ve bitiş temaları ile birlikte anılmıştır. Bunun etik sonuçlarının yanısıra politik sonuçları da olmuştur. Öte yandan yaşlılık, başlıbaşına bir konu olarak ele alınmaktan da kaçınılan bir konudur. Simone De Beauvoir konunun yeterince felsefi olmadı̆̆l, yaşlı bireyler ve yaşlılık periyodu üzerine konuşmanın önemsiz olduğu gibi çeşitli önyarglların, bu konunun felsefenin dışına itilmesine neden olduğunu belirtir. Beauvoir'ın bu saptamaları modern çağın bireyselleşme, çalışma ve tüketim odakl yaşam biçimi içerisinde yaşlı bireylerin konumuna işaret etmektedir. Gelenekten kopuşla birlikte modern yaşamın, yaşlı bireyleri tecrübe ve aktarımın özneleri olmaktan çıkartıp topluma ayak bă̆l olan kimseler olarak gördükleri açıktır. Özellikle kapitalizmin gelişmesiyle birlikte yaşlılar kamusal alanda söz sahibi olamayan, sadece bakım ve gereksinim kavramlarlyla tanımlanan bireyler haline gelmişlerdir. Bütün bu düşünme biçimleri yaş ayrımcılığını besleyen temel kaynaklardır. Bu nedenle yaşlılık hakkında daha fazla düşünmeye, yaşlılığın bilgelikle özdeşleştirildiği Antik döneme yeniden bakarak yaşlılığın farklı anlamlarını hatırlamaya ihtiyacımız vardır. Kuşkusuz bu dönemde yaşlılı̆̆ın statüsü de bugün tartışılabilir durumdadır. Ancak modern paradigmanın ve kapitalist tüketim mantı̆̆ının belirlemelerinden kurtulmak için böyle bir inceleme gereklidir. Bu makalede farklı düşünürlerin görüşlerinden faydalanılarak yaşlılı̆̆a yönelik yeni bir felsefi bakış geliştirilmeye çalışılacaktır.

Anahtar Kelimeler: Yaşlılık, yaşlı ayrımcılı̆̆ı, bilgelik, modernite, kapitalizm.

$1 \mathrm{Bu}$ makale, Assos Terence Seedsman Gero-Felsefe Okulu tarafindan, 07.05.2015 08.05.2015 tarihleri arasında düzenlenen "Yaşlanma ve Bilgelik: İyi Bir Yaşam Anlayışı için Arayış"adlı Uluslararası Sempozyumda sunulmuş, mevcut makale başlı̆̆ bildirinin geliştirilmiş ve genişletilmiş halidir.

Bu makale için önerilen kaynak gösterimi (APA 6. Sürüm):

Duva Kaya, Ö. (2020). Yaşam ve ölüm arasında bir uğrak olarak yaşl11ık. Dokuz Eylül Üniversitesi Sosyal Bilimler Enstitüsü Dergisi, 22 (4), 1501-1520

*Doç. Dr. Dokuz Eylül Üniversitesi, Edebiyat Fakültesi, Felsefe Bölümü ORCID: 00000001-7941-3198, ozlemduva@gmail.com 


\title{
AGEING AS A MOMENT BETWEEN LIFE AND DEATH ${ }^{2}$
}

\begin{abstract}
Especially in the modern period, the subjects of aging and old age have referred with the themes of death and ending. This had political consequences as well as ethical consequences. On the other hand, aging is an issue that is avoided to tackle as an issue on its own. Simone De Beauvoir states that various prejudices such as the subject is not philosophical enough, the discussion on the elderly and the old age period is insignificant, caused to exclude this issue from philosophy. These specifications of Beauvoir point to the place of elderly people in the lifestyle of modern age when is focused on individualization, work and consumption. Through the breaking with tradition, it is clear that modern life considers elderly people as a drawback in society, rather than the subjects of experience and transfer of knowledge and skills. Especially with the development of capitalism, the elderly people have become individuals who cannot have a say in the public sphere and they generally have defined only with the concepts of care and needs. All these ways of are the main sources that promote age discrimination. Therefore, we need to think more about old age, and to remember the different meanings of being elderly by taking a fresh look at the Ancient period when old age has identified with wisdom. Undoubtedly, the status of elderly people in this period is also controversial for today. Neverteheless such an investigation is necessary to escape the determinations of the modern paradigm and the capitalist consumption logic. In this article I will try to develope a new philosophical perspective on aging by making use of the views of different thinkers.
\end{abstract}

Keywords: Old age, Old-age discrimination, wisdom, modernity, capitalism.

\section{GIiRIȘ}

\author{
"Bütün gerçekler içinde, ihtiyarlık gerçeği; \\ hayatta, bütünüyle soyut bir kavram olarak \\ belki uzun süre içimizde taşıdığımız tek \\ gerçektir." (Marcel Proust)
}

Yaşlanma ve yaşlılık olgusuna bakış ne yazık ki günümüzde olduğu gibi modern çağda da « kendi başına bir mesele olarak » düşünülmeye değer bir konu gibi görülmemiş; bu yüzden de « yaşlı ayrımcılı̆̆ı » dediğimiz kavram literatüreözellikle de felsefi literatüre- görece geç bir tarihte girmiştir. Son zamanlarda daha çok tartışılmaya başlanan « yaşlılık, yaşlanma, yaşlı ayrımcılığı, uzun yaşam, aktif yaşlanma » gibi kavramların felsefi kökleri Antik Döneme kadar uzansa da modern çağın zaman, hız, tarih ve bilinç kavrayışından kendi payına düşeni almış olan bu kavramlar, özellikle kapitalizm sonrası çağda yeniden felsefenin gündemine dahil olmuştur. Yaşlanma olgusunun uzunca bir süre felsefi kanonun dışında

\footnotetext{
${ }^{2}$ This article was presented at the International Symposium, "Ageing and Wisdom: A Search for Understandings on Living Well", organized by Assos Terence Seedsman GeroPhilosophy School, between 07.05.2015 and 08.05.2015, and is the developed and extended version of the paper which has the same title of the article.
} 
bırakılmasının elbette pek çok nedeni vardır ; bunu fark edip tüm önyargılara rağmen bu konuyu ele alan Simone de Beauvoir,"Yaşlılık" adlı eserinde, kendi çağına kadar yaşl11ık olgusunun neredeyse konuşulması yasak bir konuymuş gibi görmezden gelindiğini vurgular. Beauvoir, sağlık ve bakım alanı dışında yaşlılık konusunda fikir üretenlere pek rastlanmadığı gibi, bu konuyu ele almak isteyenlerin de -sıkıcı bir konu olduğu, sadece yaşlıları veya onlara bakım verenleri ilgilendirmesi gereken bir konu olduğu, yeterince felsefi bir sorun olmadığı, vb. gibi- çeşitli gerekçelerle önemsizleştirilmek suretiyle eleştirildiğini belirtmektedir. Beauvoir'ın sözünü ettiği bu görmezden gelme davranışı, bugün de yaygın olarak tanık olduğumuz ve üstesinden gelmemiz gereken bir önyargılar kümesini içinde barındırmaktadır. Bunlardan en önemlisi, Beauvoir'ın da işaret ettiği gibi geleceği yaşl1lığa, yaşl1lığı da ölüme eşitlemektir. Bu durumda yaşl1lık, bir çöküş, bir son, üzerinde konuşmaya değer olmaktan ziyade kaçınmamız ve uzaklaşmamız gereken bir şey haline gelmektedir. Bu önyargılardan bir diğeri ise modern çağın ve özellikle kapitalizm olgusunun bir sonucu olarak çalışma hayatı içerisinde yaşlılığın bir yük, konforlu yaşamın önünde bir engel olarak görülmesidir. Bu bakış açısından da yaşlılık, üretim gücünden yoksun, işe yaramaz, kısa vadeli çıkarlar açısından bakıldığında pratikte bir yararı olmayan bir yaşam evresi olarak görülür.

Yaşlılığın gelecek perspektifimizin son noktasını, bitişi, bir nihayete erme olgusunu temsil etmesi, elbette ki biyolojik varoluşumuza ve onun sinırlılıklarına dair farkındalığımız ile de ilgilidir ancak; ölüm ve yaşlanmanın birbirine eşitlenmesinin, aslında son derece modern bir tutum olduğu söylenebilir. Tarihsel olarak bakıldığında Antiklerden modernlere kadar "ölüm bilinci" insanın kendi varoluşu, yaşamın anlamı, bu anlam ufku dahilinde kişinin etik tavrı, bireysel ve politik yaşantısı vb. üzerinde düşünmesini sağlayan bir imkan olsa da, her dönemin insan algısına dayalı olarak "ölüm" kavramının da yeniden içeriklendirildiğini görürüz.Cristoph Wulf, ölüm kavramının kültürel farkl1lıklara ve tarihsel dönemlere göre değişebilen bir tasavvur olarak toplumsal hafizada yer ettiğini belirttikten sonra, korku ve acı saçan bir olay olarak ölümün, ilk defa Hıristiyanlıkla birlikte bir yandan birtakım törensel aktiviteler, ritüeller yoluyla kabullenilmesi sağlanarak, diğer yandan ahiret yaşamı düşüncesiyle umut vadederek üstesinden gelinmeye çalışılan bir olgu haline geldiğini ifade etmiştir. Ondokuzuncu yüzyılda artık paylaşılan bir kader olmaktan ziyade bireysel bir yaşantının bir parçası olan ölüm, daha ziyade ardında bıraktıkları izlerle tanımlanmaya başlamış, çağımızda ise bireysellik vurgusunun da etkisiyle ölümün toplumsal olan ile ilişkisi giderek daha da zayıflamış ve ölüm giderek neredeyse görünmez bir hal almıştır. (Wulf, 2009, s. 244)

Wulf'un da belirttiği gibi zaman ve mekan içerisinde kök salmış olan toplumların şimdi ile yaşam arasında kurdukları bağ, yaşamın ölüm de dahil olmak üzere bütün alanlar ve aşamalar üzerindeki hakimiyetini getirmiştir. Bir yandan sağlıktaki yeni gelişmeler, yaşam sürecinin uzatılması gibi faktörlerle birlikte kendisine karşı mücadele edilen bir nihai nokta olarak işaretlenen ölüm, diğer 
yandan neredeyse yaşam savaşının kaybedildiği noktada zuhur eden ve kaçınılması gereken bir utanç meselesi haline gelmiştir. Wulf'un bu analizleri, yaşl1lık ve ölüm arasında kurulan ilişkinin tarihsel bağlamına işaret ediyor olması bakımından, Jean Baudrillard'ın modern toplumların, ölüm karşısındaki alışıldık tutumları radikal bir dönüşüme uğrattığı yönündeki görüşleriyle örtüşmektedir. Baudrillard'a göre günümüzde ölüm ve yaşamın sembolik mübadele yasalarından bütünüyle kopuşu, toplumun yaşama dair bütün düşünce ve enerjisinin, ölümün dişlanmas1 üzerinde yoğunlaşmasına neden olmuştur. (Baudrillard, 2001, s. 228) Kadim değiş-tokuş ilişkisinin yerini ölümle olan bitmez bir mücadelenin aldığı modern hayat, niteliğine bakmaksızın ve koşulsuz olarak yaşamı kutsayan, bu yanıyla da yaşamı bir kudret sembolü olarak konumlandıran karakteriyle, artık neredeyse tamamen bir güç gösterisine ve zafer hırsına odaklanmıştır. Dahası, ölüm sadece "yaşayan"ın perspektifinden değer ve anlam kazandığı için, yalnızca "hayatta kalma" açısından değerlendirilmiş ve insanlar için salt bir tehdit olarak görülmeye başlanmıştır.

Baudrillard, bu saptamaları ile, ölüm sonrası yaşam mitinde kurulan ve yaşama dair temel kavram olarak beliren iktidarın, modern dönemde ölümün geciktirilmesine duyulan arzu ve ölümün ertelenmesi olgusuyla birlikte pekiştirildiğini ima etmektedir. Başka bir deyişle yaşamanın iktidarı, Ortaçağ boyunca dini ritüeller aracılığıyla bir öte dünya inancında temellenmişken, modern dünyada da bu iktidar, daimi olarak ötelenen bir ölümden kaçış pratiğinde kendisini göstermektedir. Böylece ölüm korkusuyla yaşamlar ve hatta bedenler kontrol altına alınmakta, insanlar daha çok yönetilebilir, yönlendirilebilir, itaatkar ve tek boyutlu bireyler haline getirilmektedirler. Ölüm ise modern çağda artık insanların hesaplaşmaktan kaçındığı, yaşamın doğal seyrinin bir parçası olduğu halde, bir kaçış noktasını temsil eder hale gelmiştir.

Baudrillard'ın sözünü ettiği bu kaçış, gençleşme uğruna başvurulan tıbbi müdahalelerden yaşlanma karşıtı bakım ürünlerine, beslenme biçimimizden moda anlayışımıza ve beden algımıza, tüketim alışkanlıklarımızdan etik temellendirmelerimize kadar yaşamın her alanına sirayet eden bir dönüşümü ortaya koymakla kalmamakta, aynı zamanda Beauvoir'ın sözünü ettiği gibi yaşlanma konusuna felsefi/bilimsel/politik/etik açıdan yaklaşımımızı da belirlemektedir. Yaşamın iktidarı üzerinden planlanmış bir hayatta dışlanan veya dışarıda bırakılan bir konu olarak yaşlılık, felsefenin veya politik-etik tartışmaların kıyısında kalan bir konu olarak karşımızda durmaktadır. Yaşlılık, felsefi literatürde bile çoğunlukla bilgelik edebiyatına ait bir konu veya retorik temeldeki bir güzelleme olarak karşımıza çıkmakta, ancak ne var ki (maddi temeldeki) hazcılığın yükselişe geçtiği çağımızda artık bu söylemsel zemin, yaşlılık konusunda ufuk açıcı tartışmalar ortaya koymak açısından çok yeterli olamamaktadır. Lynne Segal, Beauvoir'ın haklı olarak işaret ettiği gibi yaşlıların, modern dünyanın « marjinalleştirilmiş öteki » sini temsil ettiği bir paradigma içerisinde normu ve norma uygunluğu temsil edenlerin « genç ve erkek-si » olarak adlandırılanlar olduğunu hatırlatır ve bu durumun, yaşlılığın modern kültür ve yazın içerisinde neden görmezden gelindiğini açıkladığını belirtir 
(Segal, 2013, ss. 9-10). Bunun yanısıra gücü temsil eden bu normatif belirlemeler, kendisini toplumda bir " mutluluk endüstrisi » üzerinden var eder ve böylece mutluluğun tüketimle özdeşleştirildiği kapitalist toplumlarda yaşlılık, yaşamın arzulanmayan bir periyodu haline gelir (Segal, 2014, s. 33). Bütün bu yorumlardan da anlaşılacağ gibi yaşamın neredeyse bir hayatta kalma eğitimi, bir savunma ve varolma stratejisi olarak cisimleştiği kapitalizm sonrası çağ, onun kendisine ait döngüsünün bir parçası olan yaşlılık evresini, yaşam alanının dışına atmaya çalışmakta; yaşl1lığı ise ölüm, son, bitiş, dahası tam bir çöküş durumu ile ilişkilendirmekte ve ölümü yadsıyarak, yaşlısız bir yaşamı kutsamaya çalışmaktadır. Çağın, ölüme en yakın evre olarak belirlenmiş yaşlılığı bir problem, ortadan kaldırılması ve üstesinden gelinmesi gereken bir bozulma hali olarak gören çalışma toplumu düzeni, bütün kurum ve pratikleriyle birlikte yaşl1lık üzerinden egemenlik kurmaya ve şiddet üretmeye devam etmektedir. Bu nedenle yaşlılığı konuşmak, biraz da bu düzenin içerisine sinmiş yaşam algısını ve bu algıya dayalı olarak ertelenen bir ölüm fikri karşısında kurulan "yaşamsız" yani "yaşlısız" bir toplum tasavvurunu konuşmak demektir.

\section{Kapitalizm ve Yaşlılık}

John Holloway, "Kapitalizmde Çatlaklar Yaratmak" adlı eserinde, kapitalizmin yarattı̆g 1 tahakkümün, ancak bir onur mücadelesi ile aşılabileceğini veya en azından onur mücadelesi içindeki hareketler yoluyla yaşama dair farkındalıklarımızın artması sonucunda, kapitalizmde çatlaklar yaratmanın mümkün olabileceğini söylemektedir. Bununla birlikte Holloway'e göre çatlaklar, genellikle "hayır" demekle başlar; yerleşik ve alışıldık olana, yaşamsal pratiklerin kalıplaşmış hallerine ve sistemi devam ettiren her türlü işleyişe karşı yöneltilen bir "hayır" sözcüğü ve tavrı, sadece bir başlangıç olarak değil, artık bir kulluk düzeninin kabul edilmediği, insanı köleleştiren her şeye karşı bir duruş ilan etmek anlamına gelir ve bu, salt bir olumsuzlama değil, aynı zamanda bir yaratma etkinliğinin başlangıcı olarak görülmelidir. (Holloway, 2010, ss. 25-29)

Holloway bu eserinde, insanların ortak noktası olarak "hayır" deme davranışının, özellikle para ve piyasa düzeninin insan etkinliklerini biçimlendirmedeki rolüne bir meydan okuma olarak, insanların yaşamlarını kendi kararları doğrultusunda belirlemeleri konusundaki bir ilk adım olarak ortaya çıktığını vurgulamaktadır. $\mathrm{Bu}$ da, çağımızda piyasa koşulları altında dışarıda bırakılan, iradeleri yok sayılan, üretim gücünden yoksun olmaları nedeniyle değersizleştirilen ve işgücü potansiyeli üzerinden tanımlanan yaş almış bireylerin maruz kaldıkları ayrımc1lık ve yok sayma pratiklerinin temel nedenlerini anlamak konusunda bize 1 şı tutmaktadır. Yaş almış bireylerin, iradelerini ve otonomilerini hiçe sayacak biçimde kamusallığın dışında bırakılmaları, onlar adına alınan ama onların iradelerinin hiçbir şekilde dahil edilmediği pratik ve uygulamaların nesnesi haline getirilmeleri, bu bireylerin « hayır » deme haklarının da ellerinden alınması 
anlamına gelmektedir. Böylece güce sahip olma yahut gücün belirlenimindeki normatif yapıya ayak uydurma davranışı meşrulaştırılmakta ve iktidar, yarattığı bir « meşru yaşam biçimi » üzerinden kendisini üretmeye devam etmektedir.

Kapitalizm koşullarında biçimlenen yaşam algısı, Baudrillard'ın sözünü ettiği " yaşamın iktidarı » meselesinin, aslında belli bir perspektiften sunulmuş bir yaşam algısının iktidarı olduğunu göstermektedir. Başka bir deyişle burada söz konusu olan aslında yaşama içkin bir kavram olan ölümün-en azından bir bitiş, sonlanma olarak yaşamla ilişkili bir kavram olmasına rağmen-yaşamdan dışlanması ve ölüm veya bitişle ilişkilendirilen her bir durum veya aşamanın da (hastalık, engellilik, yaşlılık gibi) kamusal alanın dışına atılmasıdır. Genellikle özel alan ve bakım kapsamında değerlendirilerek yaşlılık da, kamusalın dışına atılmakta, sanki özel alana aitmiş gibi tanımlanmakta ve tam da bu nedenle politik bir mesele değilmiş gibi algılanmaktadır. Oysa ki yaşlılık üzerinden kapitalist piyasa mantığının izi sürüldüğünde, konunun tam da politik problemlerin merkezinde yer aldığ görülecektir. Kitle iletişim araçları, medya, tüketim araçları vb. araçlar dolayımıyla modern birey, daima "daha iyi yaşam" koşullarıla özdeşleşmiş gençlik/canlılık/verimlilik gibi kavramlara odaklı bir yaşam tablosunun içinde düşünmeye sevkedilir. Böylece yaşamın özellikle belli bir döneminin en fazla mutluluk vadeden bir « altın çağ » olarak neredeyse kutsandığ 1 , diğer dönemlerinin ve özellikle yaşlılığın ise kaçınılan, olumsuzlamaya maruz bırakılan, güçsüzlük ve düşkünlükle özdeşleştirilen bir yaşl11ık temsilinin oluşumuna hizmet ettiği bir bakış açısına tanık oluruz.

Zamanla bu temsillerin kendileri sanki gerçeklikmiş gibi zihnimizde yer ederler ve bununla da kalmayıp, aynı zamanda pratikteki tutum ve davranışlarımızı da biçimlendirirler. Bu durumda himaye altına almak, şefkat göstermek, hoşgörmek vb. kalıplaşmış söylemler dışında, o meşhur "yaşlılara saygı" klişesinin altını dolduracak, kamusal alanda yaşlı bireyleri birer aktör, eyleyici olarak görecek herhangi bir alternatif perspektif geliştirilememiş olur. Bu nedenle yaş almış bireylerin, yaşamın birer aktörü oldukları gerçeğini ortaya koymak, öncelikle içinde yaşadığımız toplum düzenini anlamak ve sorgulamak ve dahası, buna ilişkin politik çözümlemeler ortaya koymakla mümkün olacak birşeydir. Holloway'in sözünü ettiği çatlaklar, tam da bu noktada yaratılacaktır: Deneyimin öznesi olan bireylerin, tam da deneyim üzerine konuşması ve deneyimlenen şeye, yani "olan"a ilişkin olarak "olması gereken" üzerinde 1srarcı olması, zihnimizde yer etmiş temsillerin dışına çıkarak, bize dayatılan dünyanın ve onun içindeki mutluluk ideallerinin aksine, yaşamın bütün aşamalarını ve çeşitliliğini gözetecek bir bakış açısına ulaşmak için ilk adımı atması ve aynı zamanda, içinde yaşadığımız dünyanın yeniden ve daha insancıl temellerde inşasına yönelik ümitleri barındırması açısından ufuk açıcı olacaktır.

Beauvoir'ın Yaşlılık adlı kitabını niçin yazdığını açıklamaya çalıştı̆̆ ifadeleri, bu konuda söylemek istediklerimize açıklık getirebilecek niteliktedir: 
İşte bu kitabımı, bu sessiz anlayışı bozmak için yazdım. Marcuse:" Tüketim toplumu, mutsuz bilinç yerine mutlu bir bilinç koydu ve böylece suçlu olma duygusundan styrllyor', diyerek buna dikkati çeker. Tüketim toplumu ihtiyarlar söz konusu olduğunda sadece sanık durumunda değil, aynı zamanda suçludur da. Gelişim ve bolluk efsanelerinin ardına sığınmış bu tüketim toplumu, ihtiyarlara parya muamelesi yapar, ihtiyarların oranının dünyada en yüksek olduğu, 65 yaşından yukarl olanların halkın \% 12 'sini teşkil ettiği Fransa'da bile hepsi yoksulluğa, yalnızlı̆̆a, hastalıklara, umutsuzluklara mahkum edilmişlerdir. Amerika Birleşik Devletlerinde de kaderleri daha iyi değildir. Tüketim toplumunun açıkça ögretmeye yeltendiği insancl ahlakla yine onun barbarca tutumunu uzlaştırmak için, egemen sınıf, ihtiyarları insan yerine koymamayı uygun bulur, ihtiyarları sesine kulak verilseydi, bu sesin insancul bir ses olduğunu itiraf ve kabul etmek gerekecekti. Ben, okurlarımı bu sese kulak vermeye zorlayacă̆ım: Ihtiyarlara uygulanan durumu ve bu durum içinde onların yaşayış tarzlarını tasvir edeceğim. Yalanlarla, efsanelerle, burjuva kültürünün basmakalıp sözleriyle niteliği bozulmuş olan şeyi değil, kafalarından ve yüreklerinden gerçekten geçen şeyi söyleyeceğim. İhtiyarlara sayg göstermede toplumun tutumu, oldum olastya son derece ikiyüzlüdür. (Beauvoir, 1970, s. XV)

Yaşl1lığın dışlanması aslında, emek sömürüsü üzerinde yükselen kapitalizmin çalışma ve işgücü ekseninde bir potansiyel olarak gördüğü gençliğin araçsallaştırılması ve genç-dinamik toplum modeli üzerinden bir "gelişme miti" yaratması için uygun bir çözüm gibi durmaktadır. Bunun yanı sıra toplum, yukarıda da sözünü etmiş olduğumuz bir saygı söylemini bu gelişme mitinin olası açmazları ve bu açmazların görünür olmasına karşı bir paravan olarak kullanmakta, yaşlıları, yaşamın bütün alanlarında, katılım ve sorumluluk taleplerinden vazgeçirmek suretiyle bu dar kapsamlı saygı çerçevesine hapsetmektedir. Bununla birlikte sayg1/hoşgörü adı altında yaşlılar, birer düşkün, kapasite yoksunu, zayıf bireyler olarak tanımlanmaktadırlar. Bu bakış açısı içerisinde toplumun onlara bahşettiğinden fazlasını talep etmeye layık ve hatta muktedir olamayan yaş almış bireyler, çoğu zaman "çocuksu", "çocuk gibi bakıma muhtaç", "ilgi ve şefkat gösterilmesi gereken varlıklar" olarak konumlandırılmakta, bu betimlemeler yoluyla neredeyse irade gösteremeyen, özgürce karar alamayacak, Kant'in ünlü deyişiyle "ergin olmama" halinde tanımlanan varlıklar olarak anlam kazanmaktadırlar. Böylebir bakış açısı içerisinde yaşlılık, topyekün belirlenmiş ve tanımlanmış bir kategori olarak, belirli bir dönemi kapsayan ve "doğal olarak", kendiliğinden cereyan eden ve her bir bireyde aynı biçimde tezahür eden bir aynılık kategorisi olarak iş görmektedir. $\mathrm{Bu}$ durumda her bir bireyin kendi deneyimi olmaktan çok bir doğa sorunu olarak ve biyolojik varoluşun bir gereği gibi dayatılan yaşlılık statüsü, 
bireylerde değiştirilemez, aynılaştırıcı bir nitelik gibi işlev kazanmakta ve herkesi bekleyen benzer bir « son » gibi durmaktadır. Toplum, artık belli bir yaşa gelmiş olanlardan aynı davranış kodlarını ve aynı rolleri beklemektedir. Yeniden Beauvoir'a dönecek olursak, bu noktada onun, insanların iradeleri ve yaşam deneyimlerinin çeşitliliği göz ardı edilerek bir sınır noktası tayin edilmesini net bir biçimde eleştirdiğini görürüz:

Genel olarak, toplum, ihtiyarliğa ileri yaştakilerin kurduğu bir sinıf olarak bakmaz. Ergenlik bunalımı, çocukla yetişkin arasında, ancak dar sinırlar içinde değiş̧ebilen bir işaret çizgisi çekmektedir: 18 ve 21 yaşlarındaki gençler, büyükler topluluğunda kabul edilirler. Bu tür bir geçiş, hemen hemen her zaman geçiş törenleriyle belli edilir. Politika alanında, bireyin yaşadığı süre, hak ve ödevleri aynı kalır. Medeni kanun yüz yaşındaki bir adamla kırk yaşındaki bir adam arasında hiçbir ayırım yapmaz. Hukukçulara göre; patolojik haller dışında, yaşlı insanların cezai sorumlulukları gençlerinki kadar tamdır. Günlük hayatta ihtiyarlar ayrı bir kategoriye sokulmazlar. Hoş, onlar da bunu istemezler zaten. Çocuklar ve yeni yetmeler için kitaplar, yayinlar, gösteriler, televizyon ve radyo programlar vardır. Yaşlllara yok, tabii. Böylece bu gibi durumlarda, ihtiyarlar, çok genç yetişkinlerin arasında kaynayıp gitmektedirler. Bununla beraber ihtiyarlarin ekonomik durumu söz konusu olunca, onlar, yabancı bir cinstenmiş gibi kabul edilirler, ihtiyarlara karşı insanın kendini borcunu ödemiş hissetmesi için ufak bir yardımda bulunmak yettiğine göre; onlar, diğer insanlarla ne aynı ihtiyaçlara, ne de aynı duygulara sahiptirler. Bu yanılsamayl iktisatçılar ve kanun koyucular kabul etmektedirler, ancak bu arada toplumdaki etken olmayanların yükünün etkenler tarafindan temsil edilmesinden de hoşlanmıyorlar. (Beauvoir, 1970, s. XV)

Beauvoir burada, toplum içerisinde yaşlılara biçilen roller ve onların toplumsal statüleri ile hukuksal statüleri arasındaki gerilime dikkat çekmektedir. Olağanüstü haller dışında hukuksal statülerinin diğer yetişkin bireylerle aynı kabul edildiği yaşlıların nasıl olup da diğer alanlarda -sözde- ayrıcalıklı bir statüde tanımlandıkları tam olarak açık değildir. Başka bir deyişle eğer toplumdaki yaşlılar bir suç işlediklerinde veyahut da bir sorumluluk ile yükümlendirildiklerinde kendilerine hiçbir ayrıcalık tanınmaksızın yetişkin bir birey olarak tanımlanıyor ve muamele görüyorlarsa, bunun yaşamın diğer alanlarında da geçerli olması, yani yaş almış bireylerin, yetişkinlerle aynı hayatı, onlara denk bir katılım ve aktivite olanağ 1 sağlanmak koşuluyla sürdürmeleri gerekir. $\mathrm{O}$ halde diyebiliriz ki yaşlıların diğer bireylerle eşit yurttaşlık haklarına/pratiklerine sahip olabilmeleri ve toplumsal yaşamda aktif katılımcılar olarak yer alabilmeleri için, diğer bireylerin sahip 
oldukları olanaklarla birlikte bir yaşam sürmelerinin önündeki bütün engeller kaldırılmalı ve onları diğerleriyle denk bir yurttaşlık statüsüne kavuşturacak düzenlemelere gidilmelidir. Bu noktada doğal hukuk ilkeleriyle sınırlı kalmayıp, pozitif hukukun ilkelerine başvurmak gereklidir. Pozitif haklar, bir kimsenin toplumsal konumlanmışlığını esas almaksızın hakkın öznesi olduğunu/olabileceğini varsaymanın sakıncaları konusunda bizi uyarır ve katılımcılarının asgari düzeyde birbirine denk olduğu bir kamusal yaşam inşa etme konusunda, daha adil bir dünya yaratma adına 1srar etmenin, hukuksal zemini haline gelir. Diğer yandan bu bize, hakların ve onların kullanımının, bireyin kendi işgücü ölçüsünde topluma kattığı değerden bağımsız olarak, insan olma vasfiyla ölçülebileceğini ve bu zeminde değerlendirilmesi gerektiğini hatırlatır. Oysa ki kapitalist piyasa mantığı içerisindeki metalaşma, sağlık hizmetleri de dahil pek çok alanda insan ömrünü uzatmaya yönelik çalışmaları desteklemekle birlikte, yarattığı gençlik tasarımı ve üretim gücü ile özdeşleştirilmiş konforlu yaşam algısı ile birlikte yaşlılığı, yaşam döngüsünün bir parçası olmaktan çıkarmaktadır. Böylece insanlar, bitmek bilmez bir biçimde kendi beden ve yaşam algılarıyla yüzleşmekte ve yaratılan bir "sağlıklı yaşam miti" üzerinden hayatın doğal bir periyodu sayılması gereken gençlik dönemini fetişleştirmektedirler. Bu durum, insanların gelecek perspektiflerini de etkilemekte ve geleceğin korku dolu, kaygılı bir biçimde tasarlanmasına neden olmaktadır.

Yaşl1lığın bir düşüş, bir çöküş olarak tasarlanması sonucunda, bütün insanlar; kadın veya erkek, fakir veya yoksul, kariyer/iş sahibi ya da değil, kısacası varoluş koşulları ne olursun, kültürel aidiyetleri ve kimliklerinden bağımsız bir biçimde ortak bir kaderde eşitlenmektedirler. Genellikle ölüm ve bedenin tükenişi üzerinden çeşitli söylemsel pratikler ve ritüeller ile desteklenerek oluşturulan bu çöküş/bitiş/nihayete erme algısı, insanları gençlik döneminde ayrıştıran ve farklılaştıran bütün kodları; cinsiyet, kültür, yaşam karşısında toplumsal pozisyonları bakımından elde etmiş oldukları güç vb. konulardaki farklılıkları önemsizleştirmekte ve böylece bedensel/maddi dünyanın çöküşü olarak görülen yaşl1lık, bir bitişin provası olarak anlam kazanmış olmaktadır.

$\mathrm{Bu}$ yüzden de bir kaçış refleksi içerisinde insanlar, yaşlanmamak adına zaman zaman yaşamın doğal dengesini bozabilecek operasyonlar geçirebilmekte, beslenme, tüketim alışkanlarını bir pazar ekonomisine dönüşmüş gençlik fikri uğruna değiştirebilmektedirler. Yaşlanma korkusu, insanların hayatını biçimlendiren temel kaygı olarak kaldığ 1 sürece, popüler kültürün de katkısıyla, fetişleştirilen bedenler üzerinden yaşlılık, kaçınılması ve uzaklaşılması gereken bir uğrak olarak tanımlanmaktadır. Oysa ki her bir birey ve her bir tarihsel dönem/yapı için farklı yaşl1lık deneyimlerinin olduğunu, bir insanlık durumu olarak yaşl1lığın, her ne kadar bütün insanlar için paylaşılan, birbirine benzer bir biçimde deneyimlenen bir dönem olduğunu kabul etsek de bu benzerliğin, gençliktekinden daha fazla yahut daha az olmadığını belirtmek gerekir. Gençlik her birey için aynı derecede renkli, farklılıklar ve çeşitliliklerle dolu ve canlı bir biçimde deneyimlenemeyeceği gibi, yaşlılık da 
monoton, sıkıcı, bütün kapasitelerin yitirildiği bir dönem olarak görülmemelidir. Bu tür genelleyici varsayımlar, homojen bir insan tasarımını dayattığı için problemli, bir bütün olan yaşamın aşamalarını birbirinden kopartıp her bir aşamayı ayrı varlık alanlarına sahipmiş gibi kurguladığı için de yanıltıcıdır. Aynı zamanda bir ve aynı öznede deneyimlediğimiz bedensel ve rasyonel özellikleri farklı yaşam pratikleri içerisinde ayrıştırmak, bir nevi Kartezyen felsefenin ruh-beden ayrımını dönemsel/kronolojik ayrımlar üzerinden devam ettirmek anlamına gelmektedir. Bu tür bir bakış içerisinde ve bedensel özelliklerin farklılaşması ve işlevsizleşmesi fikri üzerinden tanımlanan bir "düşüş" periyodu olarak yaşl1l1k, neredeyse ölümün prelüdü olarak, yaşamın yitirilişinden önceki son uğrağı olarak anlam kazanmaktadır. Oysa ki Platon ve ardından Kartezyen felsefenin ruh ile beden arasında kurduğu ilişki bunun aksini söylemektedir. Örneğin Platon'un bedensel olandan uzaklaşmayı ruhun özgürleşmesi olarak gören dualizmi, bedensel olandan uzaklaştıkça rasyonel yetilerin geliştiğini, ruhun bedenden kurtulduğu oranda özgürleştiğini varsayarak yaşlillğ 1 , bilgece bir yaşamın zemini olarak konumlandırmıştır. Dolayısıyla yaşl1lık bedensel olandan bir kurtuluşu temsil ettiği oranda rasyonel olanın yükselişe geçtiği bir dönem olarak konumlanmakta ve bu nedenle de bir anomali, yahut yaşamın bitişini simgeleyen ve yaşamla çelişen bir kavram olarak görülmekten kurtulmaktadır. Platoncu düşüncenin yaşlılığa dair temellendirmeleri her ne kadar politik açıdan epeyce problemli yanlara sahip olsa da bize, yaşam ve ölüm arasındaki sürecin, yani bireysel yaşantının, etik ve düşünümsel bir yanının olduğunu/olması gerektiğini hatırlatır. Platon'un hiyerarşik yapıları üreten dualizminden bağımsız bir biçimde ele alındığında onun yaşlılık üzerine söyledikleri, Beauvoir'ın da işaret etmeye çalıştığı şeyi, yani insan olduğumuzu, değişim içerisinde olduğumuzu ve ölümlü varlıklar olarak, kendi ölümsüzlük arayışımız ile yüzleşmemiz gerektiğini gösterir.

\section{Ruh-Beden Dualizmi ve Yaşılılık}

Platon'un yaşl1lık konusundaki düşünceleri özellikle onun Devlet adlı eserinde geçen ve Kephalos'la Sokrates'in diyaloğu içerisinde sürdürülen, bilgelik ve yaşl11ık ilişkisi hakkındaki tartışmada belirgin bir biçimde takip edilebilir. Bu tartışma, bedenin özellikleri olan maddi hazlar, gelip geçici olan sanı bilgisi ve yanılgılar ile ruhun erdemleri, mutlak-kesin bilgi ve hakikat arasındaki karşıtlık zemininde ilerletilir. Bilgelik eğer hakikatin bilgisine sahip olmak ise, yukarıda saydığımız birinci grup kavramlar bilgelik için bir ayakbağı olarak nitelendirilebilir. Böylece insan, Platon'un meşhur mağara alegorisinde de dile getirdiği gibi, duyusal olandan uzaklaştı̆̆ oranda hakikatin bilgisine erişebilir. Bu durumda duyusallığın yaşamda en çok köreldiği, yani en az belirleyici olduğu bir dönem olarak yaşlılık da, en bilgece davranışların gösterildiği, hakikate en yakın aşama olarak tanımlanır. Hazların gelip geçici ve yanıltıcı olmakla kalmayıp rasyonel olanın ve erdemlerin önünde bir engel teşkil ettiği düşüncesiyle Platon bu eserinde yaşlılığı, ruh-beden dualizmine dayalı olarak açıklar ve onu en makbul mertebeye, düşünme alanına 
yerleştirir. Bu yüzden bu eserinde Platon, Sokrates ve Kephalos arasında geçen diyalogda Kephalos'a şunları söyletir:

Zeus hakkl için! Ben sana ne düşündüğ̈̈mü söyleyeyim, Sokrates. (...) Bazen biz, aşă̆ yukarı yaşıt ihtiyarlar, eski atasözünün doğruluğuna örnek olarak bir araya geliyoruz. Toplandı̆̆ımız zaman arkadaşlarımızın çoğu ă̆laşır durur, gençliğin zevklerini, aşkı, şarabı, cümbüşleri, o çağın buna benzer daha başka hazlarını hatırlar, özlerler. Sanki büyük nimetlerden mahrum kalmışlar, vaktiyle pek iyi yaşadikları halde, şimdi hiç yaşamıyorlarmış gibi kederlenirler. Kimi, yaşlı olduğu için yakınlarından kötü muamele gördüğüne üzülür, bunca acılara neden olan yaşlılıktan ötürü sızlanıp durur. Ama bana öyle geliyor ki gösterdikleri neden asıl neden değildir, Sokrates; çünkü bütün bunlar yaşlıllk yüzünden olsaydl, ben de, ben yaşta olan herkes de, yaşlandığımız için aynı acıları çekerdik. Oysa aynı acıları çekmeyen başka yaşlılar da gördüm. Bir gün şair Sophokles'le beraberdim, biri gelip ona 'Aşkla aran nasıl? Hâlâ kadınlarla ilişkide bulunabiliyor musun?' diye sordu. O da 'Sus, arkadaş! Ondan kurtulduğuma bilsen ne kadar seviniyorum!' dedi, 'Sanki deli ve zalim bir efendiden yakamı slyırmışım.' Sophokles'in bu sözünü o gün doğru bulduğum gibi, bugün de doğru buluyorum. Gerçekten, yaşlllık bu şeylerde büyük bir rahatlık ve erkinlik verir; çünkü hırslar, istekler gerginliklerini kaybedip gevşeyince, tam Sophokles'in dediği olur. Insan kendini birçok deli zorbadan kurtarır. Ama bu dertlerin, hiç değilse yakınlardan çekilen dertlerin bir tek nedeni var Sokrates, o da yaşlılık değil, insanların kendi huyudur. Ölçülü, uysal olsalar, yaşlılık da o kadar zorlarına gitmez. Halbuki öyle olmayanlara yaşlılık da gençlik de ă̆ır gelir." (Platon, 1988, s. 5)

Görüldügü gibi burada Platon, yaşl1lık ile erdemler arasında doğrudan bir ilişki kurmaktadır. Bu ilişki, yaşl1lık-bilgelik kavramlarının birbirini gerektirdiği bir felsefe olarak Platon'un felsefesinin, ve özel olarak da onun gerontokratik bakışının dayanaklarını açık bir biçimde ortaya koymaktadır. Platon'un yönetim anlayışını da belirleyen gerontokrasinin, genel olarak yönetme hakkının yaştan kaynaklanan bir imtiyaz olduğu düşüncesini ifade eden bir yaklaşım olarak, birçok toplumda da kabul görmüş ve uygulanmış olduğunu belirtmek gerekir. (Lipson, 1978, s. 119).

Bilgeliğin yaşlılık ile özdeşleștirilmesi, o dönemde toplumun hafizası ve tecrübe birikiminin ifadesi olarak görülen yaşlıların, bedensel olarak ölüme yaklaştıkları anda entelektüel açıdan ölümsüzlüğe daha çok yaklaştıkları iddiasını barındırmaktadır. Bu yüzden de insan, yaşlanmaya başladıkça endişeye 
kapılmamalı, bedenin tükenişini bir son olarak görmemeli, ölümsüzlüğü ruhun/düşünmenin özgür doğasında aramalıdır. Platon burada, yaşlı Kephalos tarafından anlatılan yaşam hikâyeleri yoluyla algı ve kavram dünyası arasında bir ayrıma gider ve kavramlar yoluyla, etik temellerdeki bir yaşantıyı kurmanın imkanını açar.

Kephalos'un buradaki ifadeleri, çağımızda yaşlanma üzerine en çok çalışılan felsefi soruşturmalardan birini ortaya koyar. Daha da ötesi onun yanıtı, her biri paradoksal olarak yan yana var olabilen, Batı felsefi geleneğindeki iki temel ve birbirine karşıt geleneğin kurucuları- Platon ve Aristoteles - ve onların savunucuları ile birlikte farklı biçimler alan erdemler tartışması içerisinde değerlendirilmelidir. Filozofların derinlikli ve daimi ilgisinin bilgelik olması, Platon ve Aristoteles'in Antik Yunan dünyasındaki diğer filozoflarla birlikte geleneksel olarak rasyonel yetiler ile, yetenek ile, karakter ve beden üzerindeki yaşlanmanın etkileriyle meşgul olmaları, şaşırtıcı değildir. Onların yaşlılığı tasvir edişleri de zaman zaman birbirine karşıttır: Basit bir biçimde ifade etmek gerekirse Platon yaşın bilgeliğe, Aristoteles ise zihinsel ve fiziksel yıpranmaya yol açtığını iddia eder. Platon'un eserlerinde bu yüzden yaşlanma, basit bir dönüşüm değil, hakikate yaklaşmanın iç huzurunu, dinginliğini ve entelektüel yaşamın imkanını sunan bir mertebedir. Bu yüzden Kephalos'un dingin ve huzurlu bir varoluşun imkanı için iyi karakterin önemini savunması, aynı zamanda algı/duyu dünyasından uzaklaşıp kavram dünyasına yaklaşmak ile ilgilidir.

Platon'un buradaki aktarımına göre Kephalos'un zihninde bu düşüncelerin yeşermesini sağlayan, trajedi yazarı Sophokles'tir ve Sophokles'in trajedilerinde yaş, tecrübe ve bilgelik arasında bir ilişki kurduğu bilinmektedir. Öte yandan bu diyalog içerisinde Sokrates, ölüme yaklaşma korkusu ile yükümlülüklerini yerine getirme arzusu arasında bir bağ kurarak yaşl1lıktan ölüme doğru gidişe içkin olan, ölümden sonraki yaşam hakkındaki bir epistemolojik belirsizliğe dikkat çekecek ve bu belirsizliğin insanların adalet hakkındaki inançlarının temelini teşkil edeceğini iddia edecektir. Kephalos'un arzular, duyusallar ve algılar meselesini açmasıyla ilerleyip iyi karakter ve etik temellerdeki bir yaşam düşüncesine varan ve buradan da Platon düşüncesinden özel bir erdem türü olduğunu bildiğimiz adalete dair belirlemelerle devam eden bu akılyürütme biçimi, bilgece bir tutum ile ve gençliğinihtiras ve tutkularından arınarak gerçekleşebilecek birşeydir. Kaldı ki yaşlılığın da kendi içinde bir dinamizmi vardır; ona bu dinamizmi veren erdemlerdir ve yaşl1lığınher birey için 1zdırap olduğunu söylemek tam da bu nedenle mümkün değildir. Bununla birlikte yukarıdaki alıntıdan da anlaşılabileceği gibi yaşlılık kategorisi homojen bir kategori olmayıp, karakterin gelişim düzeyine ve yaşamı anlama ve açıklama biçimine göre farklılaşmaktadır. Sızlanan bir yaşlı olmaktan ziyade özgür bir ruha sahip bir yaşlı olabilmenin yolu da bilgece bir tutum alıştan geçmektedir. Böylece gelip geçici ve yanıltıcı ihtiraslardan ve tutkulardan uzaklaşmak, hakikate, dolayısıyla adalete ve erdemlere uygun davranmak sayesinde yaşlanmak; karakter 
ve erdemler ile ilişkilendirilmiş bir düşünüm zeminine taşınmaktadır. Bu da ancak bilge kişiler tarafından gerçekleştirilebilecek bir şeydir.

Yaşlılık-bilgelik arasında kurulan bu bağıntı, daha sonraki dönemlerde de etkin bir biçimde korunan bir düşünce haline gelir. Sokrates ve Kephalos'un Platon'un Devlet'indeki yaşlanmayla ilgili yukarıda bahsedilen tartışması, Cicero'nun Yaşlılık adlı eserinde onun yaşlılık hakkındaki düşüncelerini Cato'ya söylettiği bir diyaloğa dönüştürülerek devam ettirilir. Burada Scipio karakteri, diğer yaşlı adamların aksine Cato'ya olan hayranlığını ifade ederken, onun yaşlılığın yükünü nasıl taşıyabildiği konusunda da hayrete düşmektedir. Bu noktada Cato Platon'un Kephalos'u gibi - erdemli ve erdemli olmayan bireyler arasında bir ayrım yapar. Aslında Cato, yaş almanın erdemlere ulaştıran bir şey olduğu için iyi olduğunu iddia eder. İnsanların yaşlarına atfettiği hatalar ise, aslında yaşlılığa değil,karaktere ait hatalardır. Cicero'nun pasajı doğrudan Devlet'ten çıkarsanmış tartışmalarla içeriklendirilmiştir ve bilindiği gibi Roma felsefesinde erdemler çok önemli bir yer tutmaktadır. Bu erdemlere ulaşmak, Platon sonrasında bilgelik- yaşlılık arasındaki ilgiyi erdem temelinde kurmaya devam etmiş olan Cicero'ya görede bir ayakbağı olan ihtiras ve arzulardan kurtulmakla mümkündür ; bu kurtuluş iseancak bilgelik ruhuyla erişilebilecek birşey olduğundan, bilge insanın yaşamdaki paradoksların bilincinde olarak, yeri geldiğinde bu gerçeğe katlanmayı bilmesi gerekir :

Bana öyle geliyor ki ikiniz de pek güç olmayan bir şeye hayran oluyorsunuz; kendilerinde iyi ve mutlu ömür sürmek için azıcık yetenek olmayan kimselere her çăg ă̆ır gelir; ama her iyiliğ $i$ kendinden bekleyen insanlar için doğal zorunlulukların hiçbiri kötü görünemez. Bunların başında da yaşlılık gelir; yaşlılı̆̆a herkes ulaşmak ister, ulaşınca da onu kötüler: bilge olmayanlar işte bu derece mantıksızdirlar, bu derece dengesizdirler. Yaşlılı̆̆ın düşündüklerinden daha çabuk, sinsice geldiğini söylerler. Bir kez, bu adamlara kim, "Yanlış hesap yapın" demiş? Gençlikten yaşlilığa geçiş, çocukluktan gençliğe geçişten daha mı çabuk oluyor sanki? Sonra, insan ha seksen yaşında, ha sekiz yüz yaşında olmuş, yaşlılığın ă̆ırlı̆̆ aynı değil midir? Öyle ya, geçmiş zaman ne denli uzun olursa olsun, bir kez akıp geçti mi, düşüncesizlerin yaşlıliğını kolaylaştıracak avuntu yoktur. Diyeceğim şu ki, ĕger bilgeliğime hayransanız (keşke bu bilgelik, sizin ilginize değer ve sanıma denk olsa!), bu bilgelik en iyi önder olan doğanın, tanrıymış gibi peşinden gitmek, ona uymaktan başka bir şey değildir. Her bölümü iyi yazdlğg halde son perdeye aldırış etmeyen beceriksiz şair gibi, doğanın öbür çă̆lara önem verip de yaşlılığa aldırış etmemesi olacak şey değil. Ama tıpk ağaçta ve yerde yetişen meyvaların zamanı gelince olgunluktan geçmesi ve düşmesi gibi insan ömrünün de bir sonu olması 
zorunluydu. Bilge insan buna uysallıkla katlanır: Doğaya karşı gelmek, devlerin yaptığ gibi tanrllara kafa tutmak değil midir? (Cicero, 1998, ss. 26-27)

Görüldüğü gibi yaşl1lık, insanın ölümlü bir varlık olduğunu kabullenmesi ve ölümsüzlük idealini entelektüel plana taşıması ile işlev kazanmaktadır. Burada artık yaşl1lık entelektüel anlamdaki verimlilikle özdeşleştirilmiş ve topluma yön verecek denli önemli görülmüştür. Elbette ki buradaki verimlilik daha önce değinmiş olduğumuz kapitalizmin verimlilik anlayışından çok farklıdır; zira ortaya koymuş olduğumuz gibi kapitalizmin verimlilik anlayışı üretime dayalıdır; oysaki burada söz konusu olan entelektüel planda, toplumun ideallerini belirleyecek düşünsel anlamdaki bir verimliliktir. Genç bir insana göre yaşlı bir insanın entelektüel plandaki verimliliğinin de belli bir yaştan sonra ortaya çıktığı düşünülmektedir:

(...)Dediklerine göre, seksen bir yaşını bulan ve yazl yazarken
ölen Platon'un ömrü öyle geçmiş; Isokratesinki de öyle;
kendisinin dediğine göre, Panathenaikos adlı kitabını doksan
dört yaşındayken yazmış; ondan sonra beş yıl daha yaşamış.
Hocası Leontinoili Gorgias tam yüz yedi yıl ömür sürmüş, hiçbir
zaman da çabalamayı ve çalışmayı elden bırakmamış. Dünyada
neden öyle çok kalmak istediği sorulunca, "Yaşlılığa kötüdür
demem için hiçbir neden yok ki!" demiş. İşte parlak ve bilge
insana yakışır bir yanıt. Aklı kıt olanlarsa kendi kusurlarını,
suçlarını yaşlılığa yüklerler. (Cicero, 1998, s. 5)

Cicero'nun bu aktarımları, Platoncu paradigmanın onun tarafindan da sürdürüldüğünü gösteren, düşünmenin diğer bütün becerilerden ve yaşamsal pratiklerden daha önemli ve kalıcı olduğunu vurgulayan bir boyuta sahiptir. Yaşamın doğal döngüsü içerisinde kınanması veya olumsuzlanması gereken şey bu döngünün neresinde yer aldığımız değil; onun içinde ne şekilde yer aldığımızdır. Bu açıdan bakıldığında yaşlanmanın olumsuz yahut işlevsiz bir yaşam periyodu olmadığ 1 görülecektir ; bilakis yaş almanın kendisi bizi, daha önce hiç deneyimlemediğimiz kadar farklı bir aşamaya taşıyabilir. Bu aşamaya ulaşmak ise genellikle düşünsel ve entelektüel planda gerçekleştirilen faaliyetler yahut pratik bilgelik konusu olan şeylerle ilgilidir. Bu ise Antik dönem ve Roma dönemi kültürleri/ düşünürleri için son derece önemlidir. Elbette ki savaş becerileri, bedensel güce sahip olma vb. nitelikler o dönemde de değer gören kavramlardır ancak, bunun karşısında insanda bir de entelektüel güç olduğunu kabul eden antiklerin logos'a verdikleri değer, yaşlılığın tanımı söz konusu olduğunda daha da etkili olmaktadır:

Yaşlılar gençlerin yaptı̆̆ işleri yapmazlar, ama çok daha büyük, çok daha iyi işler görürler. Büyük işler kol gücü ya da hız ve çeviklikle değil; düşünce, sözünü geçirme, ortaya doğru düşünceler atmayla başarllır. Genellikle yaşlılar bu 
ortamlardan yoksun olmak şöyle dursun, onları arttırmışlardır bile. (Cicero, 1998, s. 5)

Böylece Platon'dan bu yana ruhun en yüksek erdemi olan düşünme etkinliği, yaşlılı̆̆ın değerini de ortaya koyan bir yetinin kullanımı, yani aklın kullanımı olarak ortaya çıkmaktadır. Burada akılyürütmenin kurnazlıkla ya da araçsal düşünme ile ilişkili olmadığı açıktır ; aksine burada aklın hakikate ve bilgeliğe dönük kullanımı söz konusudur. Bu kullanım, yaşla birlikte düşündüğümüzde eğer yeterli bir eylem ve çaba ortaya konulur ve bu çaba sürdürülürse, hayatın her döneminde mümkün olabilecek birşeydir ancak; yaşlılığın sağlayacağı bir avantajla ruhun faaliyetlerine daha da çok ağırlık verilip geliştirilebileceği yaşlılık döneminde, aklın bilgece bir tavır alışa kavuşması daha çok mümkündür. Zira Cicero'ya göre aklın kullanımı yaşl11ıkta, gençliktekinden daha az ve etkisiz değildir :

Yaşlıların aklına bir şey olmaz, yeter ki çabalarını ve eylemlerini sürdürsünler; bu, yalnızca parlak ve onurlu konumlardabulunan kimseler için değil, devlet işlerinden uzak, kendi halindebir ömür sürenler için de böyledir. Sophokles, en yaşlı zamanında bile tragedyalar yazdl; dahası, bu uğraşı yüzünden malını yönetmeyi savsakllyor gibi göründüğ̈̈ için oğulları onu mahkemeye verdiler. Bizde servetini iyi yönetemeyen babaları, mallarlyla uğraşmasını yasaklamak nasıl gelenekse; yargıçların öylece, sanki o aklını yitirmiş bir insanmış gibi, servetini elinden almalarını istiyorlardı. Dediklerine göre, o zaman yaşlı adam, elinde tuttuğu ve az önce yazmış olduğu Oidipos Kolonos'ta adlı yapıtını yargıçlara okumuş ve bu yapıtının deli işine benzeyip benzemediğini sormuş; yapıt okunduktan sonra da yargıçların kararıla aklanmış. İşte yaşlılık, bu adamı, Homeros'u, Simonides'i, Stesikhoros'u, demin söz etmiş olduğum İsokrates'i, Gorgias'ı, en büyük filozoflarl; Pythagoras'ı, Demokritos'u, Platon'u, Xenokrates'i, daha sonra Zenon'u, Kleanthes'i ya da sizin Roma'da gördüğünüz Stoacı Diogenes'i çalışmalarına son vermek zorunda bırakmış mıdır? Hepsi yaşadıkları sürece etkin de olmamışlar mıdır? (Cicero, 1998, s. 7)

Görüldüğü gibi bu düşünce içerisinde de yaşlı bir birey, yaşama dair pratik aktivitelerin, yani etik, moral, hukuksal aktivitelerin hepsini gerçekleştirmeye muktedir, bedensel alandaki bir düşüşten etkilenmekle birlikte bedene hapsolmayan, kendisini bedenin sınırlılıklarında kalarak dış dünyaya ve topluma kapatmayan ve yoluna devam eden; yani yolda olabilen; bütün bu nitelikleriyle de ortak bir ethos'un taşıyıcısı ve temsilcisi haline gelen kişi 'dir. Elbette ki burada Cicero yönetimde yaşlı bireylerin yer alması gerektiğine dair bir politik yaklaşımı da -eski geleneklere referansla- ortaya koymaktadır ancak daha temel olarak edimlerini aklıbaşındalık ve kendi yaşamını yönetebilme becerisi ile ortaya koyabilen yaşı ıireylerin 
bilgeliğinin, toplum nazarında kabul görmesi gereken bir olgu olduğunu da vurgulamaktadır. Cicero'nun bu yaklaşımı, Platon'un Devlet adlı eserinde de ortaya koymuş olduğu gibi yaşl1lığın, yargı verme kapasitesinin doruk noktasını temsil eden bir periyodu temsil etmesi ile ilgilidir. Bu düşünceye göre yaşlılığa ilişkin birtakım olumsuz kanaatler mevcut olsa da bunlar bilgeliğin ve bilgece tutumların iyi kavranamayışından, bilgelik üzerine yeterince düşünmemekten kaynaklanmaktadır. Yaşlıların bakış açılarının ve bilgeliklerinin, ancak kamu önündeki bir yargı sahnesine çıktıklarında farkında olunmakta ; yani yaşlıların bilgece tutumları değişken kanaatlerin değil, akılsal bir yargılama faaliyetinin konusu haline geldiklerinde açığa çıkarılabilmektedir. Dahası, Platon'un da ortaya koymuş olduğu gibi yargılama faaliyetine en uygun kişiler, yani en iyi yargıçlar dünyevi hazlardan, tutkulardan, hırslardan ve hubris'ten muhtemelen daha çok arınmış oldukları düşünülen yaşlı bireylerdir :

\section{"Evet," dedi, "soyluların başına gelen şey işte budur." \\ "Demek ki iyi yargıcın genç değil, yaşlı olması, ĕgriliğin doğruluğun ne olduğunu geç öğrenmesi gerek, dedim, eğriliği, ruhunda bulunan kendine özgü bir nitelik olarak tanımamış olmasl, uzun uzun deneylerden sonra onu tanlyıp ne büyük bir kötülük olduğunu anlaması, bunu da kendi yaşam deneyimleriyle değil, bilgisiyle ögrenmesi gerektir." \\ "Hiç kuşkusuz," dedim, "böyle bir yargıç, gerçekten yargıçtır." "Üstelik de iyidir, zaten sorduğun da buydu. İyidir, çünkü ruhu iyi olan iyidir." (Platon, 1998, s. 70)}

$\mathrm{Bu}$ söylemlerin arkasında yargı vermenin belirli bir zihinsel kapasite gerektirdiği, bununla birlikte yargı kapasitesinin insanı erdemlere taşıyacak bir düşünümselliği sağladığı düşüncesi vardır. Başka bir deyişle insan, ancak belirli bir olgunluk aşamasına geldikten sonra, yani bedensel hazlardan kurtulduktan sonra nesnel ve güvenilir yargılara ulaşabilir ve hakikati keşfedebilir. Bu da erdemlere ulaşmayı sağlayacak ölçüde yargı verebilmenin, yani "logos”un sesine kulak verebilmenin, duyusallardan en arınmış halde bulunan yaşlı bireyler için, daha olası bir durum olduğunu gösterir. Duyusal dünyayı, düşünmenin önünde bir engel olarak gören Platon, kendisinden sonra uzun yıllar etkili olacak erdem öğretisini, duyusal olan-düşünsel olan ayrımında cisimleşen bir ontolojik dualizm ile temellendirmiş olmaktadır. Burada yaşl11ı meselesini problematik hale getiren şey ise, gerontokrasinin temel argümanlarını tesis edecek olan akıl-tecrübe-iyilik-erdem eşitlemesidir. Platon'un düşüncesi içerisinde bu tür bir içeriklendirme ile kurulan yaşlılık-bilgelik bağı, onun yönetim anlayışını da biçimlendirmiş olmaktadır. Gerontokrasinin hegemonik boyutu ve patriyarka ile olan ilişkisi bir yana, Platon ve sonrasında bilgelik ve erdem arasında kurulan ilişkinin, açık ve net bir biçimde yaşlılık konu edinilerek tartışılmasının, özellikle kapitalizmin kamusal alanın dışına attığı yaşlıları yeniden kamusal alana dahil etmek konusunda ufuk açıcı olabileceği söylenebilir. Her ne kadar Platon ve Cicero'ya başvurarak anlatmaya çalıştığımız 
gibi yaşlılık, -her ne kadar duyusal alanın, gençliğin ve hazların üzerinde, hiyerarşik olarak onları aşan bir mertebede tanımlanmış olsa da- bugün bizlere dayatılan yaşlılık imgesinin geçerli tek imge veya yorum olmadığını göstermesi açısından önemlidir. Modern felsefenin günümüze miras bıraktığı zaman kavrayışı, Antiklerin döngüselliğinden çıkartılıp ilerlemeci bir zemine yerleştirilen yaşlılığa bakışımızı ve bu konudaki etik ve politik yaklaşımızı belirlemektedir.

Modern yaşamın insan edimlerini döngüsel bir süreçten çıkartıp kronolojik bir zaman anlayışına hapsetmesi, (Baars, 2012:8-9) salt erdemler, bilgelik ve yaşl1lık ilişkisinin dönüşümü bakımından değil, aynı zamanda politik bakımdan da pek çok problem doğurmaktadır.Geleneksel alışkanlıkların yerini yeni ve daha bireysel bir yaşam tarzının alması, bireylerin bu yeni yaşam tarzı içerisinde yeni ihtiyaçlara sahip olması ve sürekli tüketmeye yönelmesi, Baudrillard'ın da işaret ettiği gibi; yeni üretim güçlerinin ortaya çıkması, yeni ve özgül bir toplumsallaşma tarzının yaratılması ile mümkün olmuştur. (Baudrillard, 2010,s. 94-95). Bu toplumsallaşma biçimi içerisindeki tüketici kişilik özelliği, eski değerlerin yeni tüketim tarzı içerisinde kendilerine yer bulamamaları -ya da işlevsiz kalmaları- nedeniyle yeni bir değer sisteminin inşasını sağlamaktadır. Tüketim kültürünün bir başka özelliği de ölçüsüzlük ve değer yitimidir; yaşlılığa dair değersel tüketim ise hızlı ve değişken bir tüketim olgusunun önemli bir parçasıdır. Daimi olarak "yeni”ye ulaşma ve "yeni”"yi tüketme arzusu, yaşlılığı her zaman "eski"yi ve geride bırakılması gereken değer kümesini sembolize eden bir pasiflik ve hatta terkediliş durumuna indirgemektedir. Hatta Christopher Lasch, bu dönüşümlerle birlikte kapitalist toplumlarda yaygın olarak görülen bir dışlama pratiğine, yaşlanma sürecine karşı duyulan bir nefrete dikkat çekmekte ve bunun sebeplerinin sorgulanmasının son derece önemli olduğunu belirtmektedir. (Lasch, 2006, s: 325)

Elbette ki bu durum toplumun diğer üyeleri ile birlikte yaşlı bireylerin de tüketim alışkanlıklarını etkilemektedir. Moda endüstrisinden yaşlanmayı önlediğini yahut geciktirdiğini iddia eden şirketlerin büyük ölçüde etkili olduğu bir pazar ekonomisine, sosyalleşme alanlarından kamusal uygulamalara kadar pek çok faktör, yaşl1lığın sadece bir değer tüketimi haline gelmediğini, aynı zamanda bir beden tüketimi konusu haline geldiğini de gösterir. Gençleşme, sağlıklı kalma, modaya uygun davranma vb. davranışların, öncelikle tüketimi arttırmak üzere bedenleri tahakküm altına almakla bir ilişkisi vardır. (Baudrillard, 2010,s. 163). Böylece salt ekonomik ya da toplumsal planda değil, bireysel planda da değişen algilar, alışkanlıklar, zihinsel süreçler ve bilinçdışı çağrışımlarda aynı zamanda içedönük olarak da gelişen ve açığa çıkan bir dönüşüm söz konusudur (Lasch, 2006, s. 326, 327).

Özetle denilebilir ki sanayileşme sonrası toplumsal yaşamı kuran yeni ilişki biçimleri, zaman ve hız anlayışındaki dönüşümler ve çalışma hayatının kutsanması, Hannah Arendt'in deyişi ile animal laborans'in (Arendt, 2013 : 35) yüceltildiği bir dünya, emeğin araçsallaştığı, insan emeğinin kalıcı bir ürün yaratamadığı, salt 
tüketmek için çalışmanın egemen olduğu bir düzeni kurarak bu düzenin içine yerleştiği sisteme ayak uyduracak hızda ve verimlilikte olmayan her şeyi değersizleştirmektedir. Simone De Beauvoir bu durumu, kapitalist toplumlardaki kar elde etmeye dayalı ekonomilerde uzun vadeli ilgilere ve değerlere yer olmayışı, kalıcılığa değil, değişkenliğe ve gelip geçiciliğe dayalı tüketim mantığının insanın toplumdaki yerini faydacı, araçsallaştırıcı bir yolla belirlemesi üzerinden açıklar. Beauvoir'a göre çalışma toplumu, insanlık kategorisini ve değer kavrayışımızı büyük ölçüde değiştirmiştir. Yaşlı bireylerin varlık statüleri artık Antikitedeki gibi bilgelik, sabırlılık, ölçülülük vb. erdemler üzerinden değil, toplumda edindikleri ekonomik statüleri üzerinden tanımlanmaktadır. Kapitalist düzen, üretim ve tüketim ilişkileri içerisine hapsettiği insanı, yaşlandığı zaman faydasız görecek bir değer sistemi yaratmıştır. Bu yeni değer sistemi içerisinde kalarak insanlık kategorisinin dışına atılan yaşlıların kaybettikleri haklarını, yasalarla ve toplumsal statü normlarıyla sürekli yok sayılan ihtiyaç ve duygularını dikkate almak mümkün değildir. $\mathrm{Bu}$ nedenle kapitalist sömürü düzenini sona erdirmekle yaşlıların-ve özellikle yaşlanma sürecini en ağır biçimiyle deneyimleyen kadınların-daha insancıl koşullarda yaşamaları ve hakettikleri değeri görmeleri mümkün hale gelebilecektir. Böylece artık sürekli bir başkası, öteki olarak işaretlenen yaşlı bireylerin yabancı bir tür gibi ele alınışları sona erdirilebilecektir. (Beauvoir,1970, s. 68, 69) Böylece belki Holloway'ın sözünü ettiği ve öngördüğü çatlaklardan (Holloway, 2010, s. 25) birisi de yaşlı bireylerin kapitalizmin mantığı içerisindeki yerini sorgulamakla oluşturulmaya başlanacaktır.

$\mathrm{Bu}$ sorgulama, bazen de düşünme biçimimize sinmiş bazı yerleşik kavram ve kategorileri ve metodları terk etmeyi gerektirmektedir. Bu nedenle Antiklere yeniden dönmek ve yaşam, yaşlanma ve erdemler üzerine yeniden düşünmek, felsefenin kadim sorularını bugünkü bağlamlarına taşımaya ve içinde bulunduğumuz paradokslara ilişkin yeni çözümler ve yaklaşımlar geliştirmeye yardımcı olabilir. Bugün üretimin, çalışma hayatının, ekonomik düzenlemelerin, sağlık politikalarının; kısacası toplumsal yaşamı düzenleyen normların ve dayatmaların gölgesinde son derece doğalmış gibi kabul ettiğimiz pratik ve uygulamaların, kullandığımız dilin, zaman kavrayışımızın, içine dahil olduğumuz politikaların, yönetim anlayışlarının ve anlam dizgelerinin yeniden ele alınması için yaşlanma sürecine yönelik kavrayışımızın ele alınması son derece önemlidir. Yaşlılığa yönelik bir felsefi ilgiden kaçınma davranışının kökeninde yaşlılığa ilişkin temel önkabullerin ve önyargıların yattığını düşündügümüzde, bu konuyu ele almak daha elzem hale gelmektedir. Günümüzde artık çağdaş politik sorunların içerisinde yer verilmeye başlanan yaş alma meselesinin, salt bu açıdan değil, etik, ontolojik, estetik, hukuksal vb. bağlamlarda yeniden değerlendirilmesi gerekmektedir.

\section{SONUÇ}

Yaşl11ık konusu bugün gerek Batı düşüncesinde gerekse ülkemizde genellikle üretime katılma, bakım, toplumsal yaşam içerisindeki refah düzeyinin arttırılması 
vb. konularla ilişkisinde ele alınmaktadır. Bu ele alma biçimi, kapitalist üretim mantı̆̆ içerisinde artık üretim alanından dışlanan yaşlı bireylerin, herhangi bir şekilde yaşamlarını sürdürmelerine odaklanmıştır. Yirminci yüzyıldan sonra çağdaş düşünürlerin yaşlılık konusunda yazdıkları, özellikle Beauvoir ve Baudrillard'ı takip ettiğimizde karşımıza çıkan analizler, yaşlılık olgusunu düşünürken, sistemin dışına atma refleksiyle hareket ettiğimiz yaşlılar konusunda yeniden düşünmemiz gerektiğini ortaya koymaktadır. Bunun bir nedeni kapitalizmin yaşam algımızda yarattığı tahribat olabileceği gibi, diğer bir nedeni de Platon ve Platonculuk içerisinde gerontokrasinin temellerini oluşturan ve hiyerarşik olarak belirleyici bir konuma yerleştirilen bir yaşlılık kavrayışına yönelmiş bir tepki olabilir. Ancak her durumda açık olan şey, yaşlılığın sadece özel alana hapsolmuş, kamusal alandan dışlanması gereken bir mesele olarak ele alınamayacağıdır. Yaşlılığın kamusal bir mesele olarak ele alınması yaşlanma olgusuna politik açıdan yaklaşmayı gerektirse de bunun aynı zamanda etik temellerde ele alınması gereken bir mesele olduğu da açıktır. Bu nedenle kapitalizm eleştirisinin ulaştığı ve yaşlılı̆̆ın üretim gücüne endeksli bir düşünme biçimine indirgemeyeceğine dair görüşlerle, Platonculuğun, yaşl1lığın, düşünmenin ve kamusal alanda söz sahibi olmanın alanında tanımlanması gerektiğine dair duyduğu inancı etik-antropolojik bir zeminde buluşturarak, yaşlılık konusunu yeniden ele almamız ve üzerinde düşünmemiz gerekmektedir.

\section{KAYNAKÇA}

Arendt, H. (2013). İnsanlık durumu, B. S. Şener (çev.), İletişim Yayınları

Beauvoir, S. d. (1970). Yaşlılık: İlk çă̆ı, O. Canberk-E. Canberk (çev.) İstanbul: Milliyet Yayınları.

Cicero, M. T. (1998). Yaşlılık ve dostluk, A. Sarı̈öllü-T. Tunga (çev.) İstanbul: Cumhuriyet Kitapları.

Baars, J. (2012). Aging and the art of living. Baltimore: The Johns Hopkins University Press

Baudrillard, J. (2001). Simgesel değiş tokuş ve ölüm, O. Adanır (çev.) İstanbul: Boğaziçi Üniversitesi Yayınları.

Baudrillard, J. (2010). Tüketim toplumu: Söylenceleri/Yapıları, H. Deliçayl1F. Keskin (çev.) İstanbul: Ayrıntı Yayınları.

Holloway, J. (2010) Kapitalizmde çatlaklar yaratmak, B. Özçorlu-B. Doğan-S. Özer (çev.), İstanbul: Otonom Yayıncılık.

Lasch, C. (2006). Narsisizm kültürü, S. Öztürk-Ü. H. Yolsal (çev.) Ankara: Bilim ve Sanat Yayınları. 
Lipson, L. (1978). Politika biliminin temel sorunları, T. Karamustafaoğlu (çev.) Ankara: AÜ Hukuk Fakültesi Yayınları.

Platon. (1998). Devlet, A. Erhat, S. Sinanoğlu-S. Sinanoğlu, İstanbul: Cumhuriyet Gazetesi Yayınları.

Segal, L. (2013) The pleasures and the perils of ageing : Out of time, London adn Brooklyn : Verso

Segal, L. (2014) "The Coming of Age Studies », Age, Culture and Humanities, Issue : I http://ageculturehumanities.org/WP/wpcontent/uploads/2013/05/The-Coming-of-Age-StudiesSegal.pdf (İndirme Tarihi: $01.10 .2020)$

Wulf, C. (2009), Tarihsel kültürel antropoloji, Ö. D. Sarısoy, Ankara: Dipnot Yayınları. 